\title{
Economic Analysis of Manufacturing Costs of Pellet Production in the Republic of Ireland Using Non-Woody Biomass
}

\author{
Anthony Nolan ${ }^{1, *}$, Kevin Mc Donnell ${ }^{1}$, Ger J. Devlin ${ }^{1}$, John P. Carroll ${ }^{2}$ and John Finnan ${ }^{2}$ \\ ${ }^{I}$ Biosystems Engineering, UCD School of Agriculture, Food Science and Veterinary Medicine, University College Dub- \\ lin, Belfield, Dublin 4, Ireland \\ ${ }^{2}$ Teagasc Crops Research Centre, Oak Park, Carlow, Ireland
}

\begin{abstract}
An economic analysis of a non-woody biomass pelleting process was performed for conditions in the Republic of Ireland. The analysis considered the establishment, harvest, storage and drying costs of the feedstock's on-farm, together with transportation costs to the processing plant and the costs associated with the pelleting process.

Capital and operating costs of the pelleting process were estimated at several plant capacities $-6 \mathrm{t} / \mathrm{h}, 8 \mathrm{t} / \mathrm{h}$ and $10 \mathrm{t} / \mathrm{h}$. The pellet production cost for the base case scenario of $8 \mathrm{t} / \mathrm{h}$ was $€ 102 / \mathrm{t}$ of pellets produced. By decreasing production capacity to $6 \mathrm{t} / \mathrm{h}$ an increase in the production cost of $€ 10 / \mathrm{t}$ was experienced while increasing capacity to $10 \mathrm{t} / \mathrm{h}$ resulted in a decrease of $€ 6 / \mathrm{t}$ in the production cost of pellets.
\end{abstract}

The cost of the raw material is the largest cost component $(66 \%)$ of the total pellet production cost. Other major cost factors include pelleting and cooling plant (11\%), straw grinding plant (10\%) and personnel costs (9\%).

Considering current energy prices the equivalent energy cost of $€ 7$ / GJ (excluding profit margins) the potential production of non-woody biomass pellets competes favourably with oil and gas and was found to be economically viable.

Keywords: Non-woody biomass, economic analysis, production costs, storage costs, transportation costs, pelleting costs.

\section{INTRODUCTION}

Due to the posed threat of climate change, the volatile fossil fuel market and the need for an independent energy supply to sustain economic development all necessitate the need for sustainable and renewable energy resources [1]. Biomass is the most common form of renewable energy and represents the greatest opportunity as a feedstock for biofuels [2]. All types of woody biomass, agricultural residues and energy crops are suitable raw materials for pellet production [3]. Pellets are a key technology for increasing biomass use in both electricity and heat production, while research by Styles et al., 2008 has demonstrated that co-firing energy crop biomass for electricity and heat production can demonstrate substantial greenhouse gas (GHG) emission savings $[4,5]$. This is due to biomass being $\mathrm{CO}_{2}$ neutral, the emitted $\mathrm{CO}_{2}$ during combustion originates from the $\mathrm{CO}_{2}$ taken up by the biomass (closed carbon cycle), hence no increase in overall $\mathrm{CO}_{2}$ emissions [5].

In considering the cost of non-woody biomass (cereal straws - wheat, oats, barley and rape straw and energy crops - miscanthus and willow) as a feedstock for pellet production the following needs consideration:

- Establishment cost

- Harvest cost

*Address correspondence to this author at the Biosystems Engineering, UCD School of Agriculture, Food Science and Veterinary Medicine, University College Dublin, Belfield, Dublin 4, Ireland; Tel: +353 17167484 ; Fax: +353 1716 7415; E-mail: anthony.nolan@ucd.ie
- Storage cost

- Transport cost [6].

Harvesting represents one of the most significant costs in the production of biomass feedstock [2]. The method of harvest influences both the storage and transport costs [6]. Due to the low bulk density of agricultural cereal straws and energy crops the transportation payload is low with the result that transport can account for $70 \%$ of the total biomass fuel cost $[2,6,7]$. Previous research conducted by McKendry, 2002 into the production cost of non-woody biomass has reported costs of $€ 45 /$ tonnes dry matter $(£ 28 / \mathrm{t} \mathrm{dm})$ for cereal straw and $€ 75$ / tonnes dry matter and $€ 86$ / tonnes dry matter ( $£ 47 / \mathrm{t} \mathrm{dm}$ and $£ 54 / \mathrm{t} \mathrm{dm}$ ) for short rotation coppice and miscanthus respectively (2002 exchange rate Pound Sterling to Euro) [2, 8]. Styles et al., 2008 reported production costs in Ireland of between $€ 37-48 / \mathrm{t} \mathrm{dm}$ for miscanthus and $€ 31-46 / \mathrm{t} d \mathrm{~m}$ for short rotation coppice willow [5]. In Denmark the production cost for big bales of straw $(1.2 \mathrm{~m} \times 1.2 \mathrm{~m} \times 2.4 \mathrm{~m})$ delivered to the pellet plant is $€ 61 / \mathrm{t}$ @ 15\% moisture content [9].

The storage of biomass is generally on farm prior to pelleting [6]. Biomass storage can take many different forms:

- Storage in the open air, with or without covering

- Storage in existing or new farm buildings

From previous research conducted by Nolan et al., 2009 it can be concluded that covered storage of some form is essential to guarantee a year round supply of quality, dry 
feedstock [11]. Storage costs are lowest when the density of the material is high [6]. Drying of the biomass can take place either in the field if weather prevails, in on-farm storage or at the industrial installation [10]. Drying generally takes place in on-farm storage (under plastic or roofed storage) $[6,11]$. When considering the moisture content of agricultural cereal straws and energy crops many raw materials can be delivered at moisture content of less than $20 \%$ neglecting the need for drying of the biomass [3]. Under the research conducted by Nolan et al., 2009 miscanthus bales with an initial moisture content of 39\% moisture content wet basis was dried to under $20 \%$ in covered storage using natural ventilation of ambient air [11].

Transport costs are largely a function of the distance travelled and the energy density of the biomass type and transport form (chip or baled) [2]. Transportation of biomass can be in the form of chipped, chipped and compacted or baled utilising a truck with semi-trailer ( 1 or 3 axle), truck with trailer, container transport ( 2 or 3 axle) or agricultural tractor and trailer [6]. An average payload of $14.7 \mathrm{t} \mathrm{dm}$ can be achieved for baled material (bulk density $145 \mathrm{~kg} \mathrm{dm} \mathrm{/}$ $\mathrm{m}^{3}$ ), $11.2 \mathrm{t} \mathrm{dm}$ for chipped material (bulk density $100 \mathrm{~kg} \mathrm{dm}$ $/ \mathrm{m}^{3}$ ) and $30 \mathrm{tdm}$ for chipped and compacted material (bulk density $265 \mathrm{~kg} \mathrm{dm} / \mathrm{m}^{3}$ ) [6,12]. According to research conducted by Huisman et al., 1997 the average transport cost for baled material is $€ 1.07 / \mathrm{km}$ (payload 14.7 tonnes $\mathrm{dm}$ ), for chipped material $€ 1.07 / \mathrm{km}$ (payload 11.2 tonnes $\mathrm{dm}$ ) and for chipped and compacted material is $€ 1.15 / \mathrm{km}$ (payload 30 tonnes $\mathrm{dm}$ ) [6]. Research conducted by Garstang, 2002 calculates the cost of baled transport at $€ 0.13 / \mathrm{km} / \mathrm{t} \mathrm{dm}$ (£0.08/ km / t dm) and chipped transport at $€ 0.21 / \mathrm{km} / \mathrm{t}$ $\mathrm{dm}(£ 0.13 / \mathrm{km} / \mathrm{t} \mathrm{dm})(2002$ exchange rate Pound Sterling to Euro) [12].

An economic analysis of the production of biofuel pellets utilising non-woody biomass as a raw material should consider not only the feedstock cost but also the plant capacity, drying cost and plant utilisation time [7]. The capital cost of any plant depends on the material [13]. For wood waste the moisture content of the raw material is optimum between 10 $-12 \%$ [14]. A typical pelleting process involves the majority if not all of the following operations:

- Primary grinder

- Secondary grinder

- Drying

- Pellet mill

- Cooling

- Bagging of pellets [7, 12-14].

Densification or pelleting of the raw material is achieved by forcing the raw material under high pressure and temperature through the die openings $[7,14]$. The resulting pellets are cylindrical, of $6-8 \mathrm{~mm}$ diameter and $10-12 \mathrm{~mm}$ long [7]. Depending on the particle size and form of the biomass two grinding operations may be required to achieve a maximum particle size less than that of the pellet diameter [13]. Such a grinding operation is necessary for baled biomass or whole logs. Pelleting non-woody biomass increases the bulk density of the material from approximately $30 \mathrm{~kg} / \mathrm{m}^{3}$ to between 550 and $700 \mathrm{~kg} / \mathrm{m}^{3}$ [7].
Previous research has being conducted to investigate the economics of producing pellets from biomass. Research conducted by Mani et al., 2006 evaluated pellet production costs at $€ 38 /$ tonne ( $\$ 51 /$ tonne - 2006 exchange rate U.S Dollar to Euro: capital cost - $\$ 6 /$ tonne and operating cost $\$ 45 /$ tonne) [7, 16,17]. Thek and Obernberger, 2004 compared the cost of producing pellets under Austrian and Swedish framework conditions [15]. Under Swedish conditions pellets could be produced at $€ 62.40$ / tonne compared with $€ 90.70$ / tonne under Austrian framework conditions. The main reasons for this are larger plant capacities, greater dryer efficiency through heat recovery and lower electricity cost (Sweden - €3.7 / tonne and Austria - €7.5 / tonne) [15]. The major cost factors in the production of pellets from biomass are the raw material costs and personnel costs [7]. After these costs the cost of drying is a considerable factor depending on the type of dryer technology and fuel used. If heat recovery from the process is possible or if heat recovery from CHP can be utilised for drying the efficiency of the drying process is greater and the cost reduced [7, 15]. The production costs of pellets are affected by feedstock price, plant capacity and plant utilisation. The greater the plants production capacity (tonnes / hour) and hours of operation and the lower the feedstock cost ( $€ /$ tonne) the lower the production cost per tonne of pellets [1, 12-15]. Mani et al., 2006 reports a production cost of $€ 29.68$ / tonne ( $\$ 39$ / tonne - 2006 exchange rate U.S Dollar to Euro) for biomass pellets if drying is not required (as is for the case for some nonwoody biomass) [7]. The major cost factors in producing biomass pellets as a percentage of the overall production cost are as follows:

- Raw material: $40 \%$

- Drying: $20-30 \%$

- Personnel: $13-25 \%[7,12]$.

To determine the economic viability and effect of scale of producing biofuel pellets from non-woody biomass in Ireland a detailed analysis of the process is required. In conducting the analysis plant capacity, utilisation of the plant, capital cost and operating cost per tonne of pellets produced will be evaluated under Irish framework conditions. All types of non-woody biomass (cereal straws and energy crops) will be considered as feedstock for the pelleting process. The production cost for all feedstocks will be determined and the economy of scale for pellet production assessed.

\section{METHODOLOGY}

In analysing the economic cost of producing pellets from non-woody biomass the first step is to analyse the feedstock cost. In determining the cost of non-woody biomass the following is to be considered:

- Crop production cost (establishment and harvest)

- Storage cost

- Drying cost

- Transport cost

Non-woody biomass for the context of this research study consists of cereal straws (wheat, oats, barley and rape) and energy crops (miscanthus and willow). After determin- 
ing the cost of biomass delivered to the production facility, the cost of producing pellets must be determined considering the capital costs and operation costs of a pellet production facility. The capital costs for a pelleting plant consist of the following:

- Land cost

- Machine purchase, installation and maintenance

- Offices

- Auxiliary equipment - loaders, etc.

The operating costs for a pelleting plant consist of the following:

- Raw material cost

- Drying cost

- Electricity cost

- Personnel cost

Upon determining the costs associated with the pelleting process the cost per tonne of pellets for various feedstocks and plant capacities will be evaluated. From this cost the economic viability of producing fuel pellets from non-woody biomass in Ireland will be determined.

\subsection{Crop Production Costs (Establishment and Harvest)}

In determining the cost of non-woody biomass crops, two approaches are to be considered:

1. crop production costs (Teagasc farm management handbook 2008) [18]

2. opportunity cost of the biomass [19]

Depending on the existence of developed markets for a given biomass production costs may be calculated using either or both of the approaches. For wheat, oat and barley straw both approaches will be considered due to already existing markets for straw. The opportunity cost of straw as a fertilizer when chopped and ploughed back at sowing. As rape straw has no value other than as a fertilizer when ploughed back at sowing the opportunity cost will be considered.

\subsection{Storage Costs}

To ensure a year round supply of quality, dry biomass covered storage is essential. For pellet production biomass should be between approximately $12-18 \%$ moisture content wet basis (m.c.w.b). The storage of cereal straws and miscanthus is best facilitated in bale form either in roofed structures or under reinforced plastic. Willow is generally stored in chip form either in roofed structures or under plastic cover.

\subsection{Drying Costs}

As most cereal straws are harvested at moisture contents below 20\% moisture content wet basis (m.c.w.b) minimal drying is required. For baled material drying by natural ventilation in storage is adequate to maintain a quality, dry material (wheat, oats, barley, rape straw and miscanthus). Considering the high moisture content of willow at harvest (often in excess of $50 \%$ m.c.w.b.) forced ventilation for drying willow in chip form is essential. Forced ventilation can be fa- cilitated using pipes under the pile (outdoor storage or existing buildings) or ventilation ducts built-in to the floor (new or specialised buildings).

\subsection{Transportation Costs}

When transporting non-woody biomass densification of the biomass in some form is essential due to the low bulk density of the material in general (straw $-30 \mathrm{~kg} / \mathrm{m}^{3}$ and miscanthus $-80 \mathrm{~kg} / \mathrm{m}^{3}$ ). Even when baled density and payloads are still low for biomass (straw baled $-100-200 \mathrm{~kg} / \mathrm{m}^{3}$, miscanthus baled $130 \mathrm{~kg} / \mathrm{m}^{3}$ and willow chip $140 \mathrm{~kg} / \mathrm{m}^{3}$ ) [6, 12]. For baled material, transportation is via an articulated truck or agricultural tractor with flatbed trailer. Chipped material is transported by either an articulated truck and stepframe trailer or container or by agricultural tractor and high sided trailer. Where transport distances are short (less than 50 kilometres) transportation via agricultural tractor combination may be preferred.

\subsection{Overall Cost of Raw Material Delivered to the Pellet Plant}

The overall cost of non-woody biomass includes the cost of crop production, storage and transportation. This ensures a year round delivery of material to the processing plant without the need for large storage and drying facilities at the plant. All costs are at a base cost and do not consider profit margins.

\subsection{Pellet Production Costs}

Pelleting costs include fixed (capital) costs and operating costs. The capital cost consists of land cost, buildings, plant equipment, installation and maintenance, forklifts and loaders. An interest rate of 7\% will be assumed while maintenance of plant and building will be $2 \%$ of the capital cost with exception of the pellet and hammer mill (10\% of capital) due to the high wear of parts. Operational costs include raw material, heat energy for drying, electricity and personnel costs. The total capital and production costs are calculated according to the following equations used by Mani et al., 2006 [7].

$$
\text { Total Capital Cost, } \mathrm{C}_{\mathrm{c}}(€ / \text { year) - }
$$

$$
C_{c}=e C_{e q}
$$

where:

$$
\begin{aligned}
& \mathrm{e}=\text { capital recovery factor } \\
& \mathrm{C}_{\mathrm{eq}}=\text { cost of equipment }
\end{aligned}
$$

The capital recovery factor is calculated using the formula:

$$
e=\frac{i(1+i)^{N}}{(1+i)^{N}-1}
$$

where:

$\mathrm{i}=$ interest rate (expressed as a decimal)

$\mathrm{N}=$ lifetime of the equipment (years)

When the cost of equipment for a specific given capacity was unavailable the following equation derived from cost versus capacity relationship was used to determine the equipment cost. 
Table 1. Crop Production Costs and Yield Per Hectare

\begin{tabular}{|c|c|c|c|c|c|c|}
\hline \multirow[t]{2}{*}{ Biomass } & \multirow{2}{*}{$\begin{array}{c}\text { Yield } \\
\text { (t / ha dm) }\end{array}$} & \multicolumn{2}{|c|}{$\begin{array}{c}\text { Production Cost } \\
\text { (dm) }\end{array}$} & \multicolumn{2}{|c|}{ Opportunity Cost (dm) } & \multirow{2}{*}{$\begin{array}{c}\text { Baling }(1.2 \times 1.2 \times 2.4 \mathrm{~m}) \\
(€ / \mathrm{t} \mathrm{dm})^{*}\end{array}$} \\
\hline & & $(€ /$ ha) & $(€ / t)$ & $(€ /$ ha $)$ & $(€ / t)$ & \\
\hline Wheat straw & 4.7 & $70-85^{1}$ & 16.50 & $86-91^{2}$ & 19 & 15 \\
\hline Barley straw & 3.5 & $100-110^{1}$ & 30 & $64-70^{2}$ & 19 & 15 \\
\hline Oaten straw & 3.6 & $100^{1}$ & 28 & $95-107^{2}$ & 28 & 15 \\
\hline Rape straw & 1.9 & N/A & N/A & 36 & 18.95 & 15 \\
\hline Miscanthus & 10 & $510^{1}$ & $51^{3}$ & N/A & N/A & Inclusive $^{3}$ \\
\hline Willow & 10 & $820^{1}$ & 82 & N/A & N/A & N/A \\
\hline
\end{tabular}

Source: Teagasc farm management data $2008^{1}$ [18]

Straw fertilizer value - Teagasc Crops Research Centre ${ }^{2}$ [19]

* Assuming average bale mass of $500 \mathrm{~kg} \mathrm{dm} @$ contractor costs of $€ 7.50$ / bale [18]

$$
C_{e q 1}=C_{e q 2}\left(\frac{C_{1}}{C_{2}}\right)^{g}
$$

where:

$\mathrm{C}_{1}$ and $\mathrm{C}_{2}=$ equipment capacity

$\mathrm{g}=$ exponent - for process equipment the exponent ranges from $0.4-0.8$

Previous research conducted into the economics of producing pellets from woody biomass utilised an exponent value of 0.6 which will also be considered for this study.

The total cost (capital and operational cost), $\mathrm{C}_{\mathrm{T}}$, is given by the equation:

$$
C_{T}=C_{c}+C_{o p}
$$

where:

$\mathrm{C}_{\mathrm{op}}=$ operating cost $(€ /$ year $)$

The final production cost, $\mathrm{Cp}$ (€/tonne), for the production of biofuel pellets may be calculated from the equation:

$$
C_{p}=\frac{C_{T}}{t_{o p} G_{p}}
$$

where:

$\mathrm{t}_{\mathrm{op}}=$ total operational hours of the plant per year (hrs/year)

$\mathrm{G}_{\mathrm{p}}=$ production rate $(\mathrm{t} / \mathrm{h})$

The purchase cost of equipment was collected from equipment manufacturers and suppliers. Installation cost for the plant equipment was taken from previous research conducted by Mani et al., 2006 and varies from $40 \%$ to $75 \%$ of the purchase cost. No steam conditioning or external binders are considered. The pelleting costs are calculated on three production capacity scenarios: $6 \mathrm{t} / \mathrm{h}, 8 \mathrm{t} / \mathrm{h}$ and $10 \mathrm{t} / \mathrm{h}$. As aforementioned all costs are base costs and do not include any profit margins.

\section{RESULTS AND DISCUSSION}

\subsection{Crop Production Costs (Establishment and Harvest)}

The straw market is changeable from year to year depending on the weather conditions and the yield of straw at harvest time. On average the straw yield from wheat, oats and barley is considered to be $60 \%$ of the grain yield ${ }^{1}$. Straw prices differ from crop to crop. Cereal crops are sown and harvested annually.

In calculating the production costs for energy crops the harvest method is critical. For miscanthus the crop was mowed and baled while willow was cut and chipped with a self-propelled harvester. When planting miscanthus a full yield is obtained after the third year of growth and is harvested annually. Willow on the other hand is harvested every two years with the first full yield crop obtained after the forth year. Both willow and miscanthus are perennial crops with a growth life of $15-20$ years.

The production costs of non-woody biomass include crop establishment (soil preparation, planting and crop management) and harvesting. Table $\mathbf{1}$ summarises the production costs and expected yield for each crop.

\subsection{Storage Costs}

For the purpose of calculating storage costs for baled biomass the following assumptions were made:

1. Two types of roofed structure are considered:

- $\quad$ Roofed with no side sheeting (structure 1)

- $\quad$ Roofed and sheeted 1/3 down the side (structure 2)

2. Two types of cover are considered:

- heavy duty 1200 gauge plastic

- Tarpaulin

\footnotetext{
${ }^{1}$ Teagasc Crops Research Centre, Oak Park, Carlow, Ireland. Personal communication - Tillage and Energy crop Advisors.
} 
Table 2. Storage Costs of Non-Woody Biomass

\begin{tabular}{|c|c|c|}
\hline Storage Type & Storage Form & Storage Cost $(€ / \mathrm{a} / \mathrm{t} \mathrm{dm})$ \\
\hline Roofed Structure: & & Euro / annum / tonne dry matter \\
\hline Structure 1 & $1.2 \times 1.2 \times 2.4 \mathrm{~m}$ Bale & $1.69^{*}$ \\
\hline Structure 2 & $1.2 \times 1.2 \times 2.4 \mathrm{~m}$ Bale & $1.80^{*}$ \\
\hline \multicolumn{3}{|l|}{ Covered: } \\
\hline 1200 Gauge Plastic & $1.2 \times 1.2 \times 2.4 \mathrm{~m}$ Bale & $1.43^{*}$ \\
\hline Tarpaulin & $1.2 \times 1.2 \times 2.4 \mathrm{~m}$ Bale & $2.05^{*}$ \\
\hline Chip Heap (27 x 14 x 2m) & Chip & $6.42^{-}$ \\
\hline
\end{tabular}

* Storage costs includes sub-base of hardcore filling (Labour for base excluded)

Storage costs includes sub-base of hardcore filling and concrete floor (Labour for base and floor excluded)

Table 3. Drying Costs of Non-Woody Biomass in Storage

\begin{tabular}{|l|c|c|c|}
\hline Biomass & Storage Form & Drying Medium & Cost (€ /a / dm) \\
\hline \hline Wheat straw & $1.2 \times 1.2 \times 2.4 \mathrm{~m}$ Bale & Natural Ventilation & Nil \\
\hline Barley straw & $1.2 \times 1.2 \times 2.4 \mathrm{~m} \mathrm{Bale}$ & Natural Ventilation & Nil \\
\hline Oaten straw & $1.2 \times 1.2 \times 2.4 \mathrm{~m} \mathrm{Bale}$ & Natural Ventilation & Nil \\
\hline Rape straw & $1.2 \times 1.2 \times 2.4 \mathrm{~m} \mathrm{Bale}$ & Natural Ventilation & Nil \\
\hline Miscanthus & $1.2 \times 1.2 \times 2.4 \mathrm{~m} \mathrm{Bale}$ & Natural Ventilation & 7 \\
\hline Willow & Chip & Forced Ventilation* & \\
\hline
\end{tabular}

Source: Teagasc Crops Research Centre [1]

*Ambient air

Willow chip is stored on a concrete yard and covered using plastic or a tarpaulin. Mechanical or forced ventilation is necessary to dry the chip and prevent heating as harvest moisture can be as high as $50 \%$ m.c.w.b. Storage costs are described in Table 2.

\subsection{Drying Costs}

Baled biomass was dried in covered storage using natural ventilation to between 15 and $20 \%$ m.c.w.b. over a period of 6 - 9 months, depending on the initial moisture content of the biomass. Willow chips were dried using forced ventilation at ambient temperature. Storage was under plastic covering for a period of 4 months. The average moisture content was 18 to $25 \%$ m.c.w.b. Drying of willow indoors with built-in under floor ventilation ducting can utilise either ambient or heated forced ventilation. The costs occurred in the drying of biomass as discussed above are summarised in Table $\mathbf{3}$.

\subsection{Transportation Costs}

In transporting baled biomass $(1.2 \mathrm{~m} \times 1.2 \mathrm{~m} \times 2.4 \mathrm{~m}$ large bales) the average maximum load capacity is $15 \mathrm{t} \mathrm{dm}$. An average bale mass of $500 \mathrm{~kg} \mathrm{dm}\left(145 \mathrm{~kg} \mathrm{dm} / \mathrm{m}^{3}\right)$ is assumed with 30 bales per load. These trailer and load dimensions comply with the Irish road Traffic Regulations, 1963, SI 190 of 1963 (Construction, equipment and use of vehicles) [20]. The load capacity is a configuration of a $6 \times 2$ articulated tractor unit and flatbed trailer (12.2m in length) or an agricultural tractor and flatbed trailer (12.2m in length).

For chip haulage a maximum load capacity of 7 tonnes dry matter $\left(140 \mathrm{~kg} \mathrm{dm} / \mathrm{m}^{3}\right)$ is obtained for a $50 \mathrm{~m}^{3}$ volume trailer. The maximum load capacity for a $100 \mathrm{~m}^{3}$ volume trailer is 14.5 tonnes dry matter $\left(145 \mathrm{~kg} \mathrm{dm} / \mathrm{m}^{3}\right)$. Both these load configurations are a $6 \times 2$ articulated tractor unit and trailer.

When the travel distance is less than 50 kilometres an agricultural tractor combination is a more cost effective and efficient method of transportation. Articulated haulage costs for both baled and chipped material are obtained from a derived transport model. The costs associated with the use of agricultural vehicles for haulage are $€ 0.12 / \mathrm{km} / \mathrm{t} \mathrm{dm}$ for baled material and $€ 0.25 / \mathrm{km} / \mathrm{t} \mathrm{dm}$ for chipped material. These costs were obtained from current biomass operations utilising such transport. The associated transport costs are detailed in Table 4.

\subsection{Overall Cost of Non-Woody Biomass Delivered to the Pellet Plant}

The farm gate price (production, storage and drying costs) together with the transportation costs of the biomass represents the overall cost of raw material supplied to the production facility. Table $\mathbf{5}$ details the cost of supplied biomass. 
Table 4. Transportation Costs of Non-Woody Biomass

\begin{tabular}{|c|c|c|c|c|c|}
\hline \multirow{2}{*}{$\begin{array}{l}\text { Haulage Type } \\
\text { Tractor \& Flatbed Trailer }(12 \mathrm{~m})\end{array}$} & \multirow{2}{*}{$\frac{\text { Max Load (t dm) }}{15}$} & \multicolumn{2}{|c|}{$€ / \mathrm{km} / \mathrm{t} \mathrm{dm}$} & \multicolumn{2}{|c|}{$50 \mathrm{~km}(€ / \mathrm{t} \mathrm{dm})$} \\
\hline & & $0.12^{1}$ & $0.12^{1}$ & 6 & 6 \\
\hline Tractor \& High-Sided Trailer & 8 & $0.25^{1}$ & $0.25^{1}$ & 12.50 & 12.50 \\
\hline Articulated Unit \& Flatbed Trailer (5 axles) & 15 & $0.27^{2}$ & $0.29^{3}$ & 13.50 & 14.50 \\
\hline Articulated Unit \& chip van (6 axles) & 14.5 & $0.24^{2}$ & $0.26^{3}$ & 12 & 13 \\
\hline \multicolumn{6}{|l|}{$\begin{array}{l}\text { Source: FITPAC Transport Model [21] } \\
{ }^{1} \text { Agricultural Diesel Fuel Cost } 0.77 € / \text { litre } \\
{ }^{2} \text { Diesel Fuel Cost } 0.91 € / \text { litre } \\
{ }^{3} \text { Diesel Fuel Cost } 1.24 € / \text { litre }\end{array}$} \\
\hline
\end{tabular}

Table 5. Overall Cost of Non-Woody Biomass as Material Source

\begin{tabular}{|c|c|c|c|c|c|c|}
\hline Biomass Type & Wheat Straw & Barley Straw & Oaten Straw & Rape Straw & Miscanthus & Willow \\
\hline Production & 31.50 & 45 & 43 & N/A & 51 & 82 \\
\hline Opportunity & 34 & 34 & 43 & 33.95 & N/A & N/A \\
\hline Structure 1 & 1.69 & 1.69 & 1.69 & 1.69 & 1.69 & N/A \\
\hline Structure 2 & 1.80 & 1.80 & 1.80 & 1.80 & 1.80 & N/A \\
\hline 1200 Gauge Plastic & 1.43 & 1.43 & 1.43 & 1.43 & 1.43 & N/A \\
\hline Tarpaulin & 2.05 & 2.05 & 2.05 & 2.05 & 2.05 & N/A \\
\hline Forced Ventilation & N/A & N/A & N/A & N/A & N/A & 7.00 \\
\hline \multicolumn{7}{|c|}{ Transport Cost $(€ / \mathbf{t ~ d m})$ - average distance $50 \mathrm{~km}$} \\
\hline $\begin{array}{l}\text { Tractor \& Flatbed Trailer } \\
(12 \mathrm{~m})\end{array}$ & 6 & 6 & 6 & 6 & 6 & N/A \\
\hline $\begin{array}{l}\text { Tractor \& High-sided } \\
\text { Trailer }\end{array}$ & N/A & N/A & N/A & N/A & N/A & 12.50 \\
\hline $\begin{array}{l}\text { Articulated Unit \& Flat- } \\
\text { bed Trailer ( } 5 \text { axles) }\end{array}$ & 14.50 & 14.50 & 14.50 & 14.50 & 14.50 & N/A \\
\hline \multicolumn{7}{|c|}{ Total (lowest cost option $-€ / \mathbf{t ~ d m )}$} \\
\hline
\end{tabular}

\subsection{Pellet Production Costs}

The production capacity of the pelleting plant for the base case scenario is $8 \mathrm{t} / \mathrm{h}$ with an annual production of $45,440 t$. The plant operates 24 hours per day from October to
April and 8 hours per day from May to September. This is considered to be the summer period where pellet demand for heating purposes would be considerably less. The operating hours of the plant are corrected for an annual utilisation period of $90 \%$ resulting in a total of 5,680 production hour's 
Table 6. Initial Capital Cost of Equipment for the Pellet Production Plant (Base Case -8 t/h Production)

\begin{tabular}{|c|c|c|c|c|c|c|}
\hline Equipment & $\begin{array}{c}\text { Purchase Cost } \\
\qquad(000 €)\end{array}$ & $\begin{array}{c}\text { Installation (000 } \\
€)\end{array}$ & $\begin{array}{c}\text { Expected Life } \\
(\mathrm{yrs})\end{array}$ & $\begin{array}{l}\text { Capital Recov- } \\
\text { ery Factor }\end{array}$ & $\begin{array}{c}\text { Annual Capital } \\
\text { Cost }(000 €)\end{array}$ & $\begin{array}{l}\text { Specific Capi- } \\
\text { tal Cost }(€ / t)\end{array}$ \\
\hline Straw Grinding Plant & 405.34 & 162.14 & 10 & 0.1424 & 80.8 & 1.78 \\
\hline Pelleting \& Cooling Plant & 515.70 & 273.32 & 10 & 0.1424 & 112.34 & 2.47 \\
\hline Misc. Elec. Equipment & 272 & - & 15 & 0.1098 & 29.86 & 0.66 \\
\hline Compressed Air Plant & 9.08 & 0.91 & 15 & 0.1098 & 1.10 & 0.02 \\
\hline Packaging Unit & 120 & 22.8 & 15 & 0.1098 & 15.68 & 0.35 \\
\hline Storage Bin & 20 & 2.8 & 15 & 0.1098 & 2.50 & 0.06 \\
\hline Industrial Loader & 95 & - & 10 & 0.1424 & 13.53 & 0.30 \\
\hline Fork Lift Truck & 11 & - & 10 & 0.1424 & 1.57 & 0.03 \\
\hline Office \& Building & 450 & - & 20 & 0.0944 & 42.48 & 0.93 \\
\hline Land Use & 200 & - & 25 & 0.0858 & 17.16 & 0.38 \\
\hline Total & 2098.12 & 461.97 & - & - & 317.01 & 6.98 \\
\hline
\end{tabular}

Table 7. Effect of Annual Production Capacity on the Initial Capital Cost of Equipment

\begin{tabular}{|c|c|c|c|c|c|c|}
\hline $\begin{array}{c}\text { Production Capacity } \\
\text { (t / h) }\end{array}$ & $\begin{array}{c}\text { Purchase } \\
\text { Cost } \\
(000 €)\end{array}$ & Installation $(000 €)$ & $\begin{array}{c}\text { Expected Life } \\
(\text { yrs })\end{array}$ & $\begin{array}{l}\text { Capital Recov- } \\
\text { ery Factor }\end{array}$ & $\begin{array}{c}\text { Annual Capital Cost } \\
(000 €)\end{array}$ & $\begin{array}{c}\text { Specific Capital } \\
\text { Cost }(€ / t)\end{array}$ \\
\hline \multicolumn{7}{|l|}{$6 \mathrm{t} / \mathrm{h}$} \\
\hline Total & 1952.10 & 392.93 & N/A & N/A & 286.39 & 8.40 \\
\hline \multicolumn{7}{|l|}{$8 \mathrm{t} / \mathrm{h}$} \\
\hline Total & 2098.12 & 461.97 & N/A & N/A & 317.01 & 6.98 \\
\hline \multicolumn{7}{|l|}{$10 \mathrm{t} / \mathrm{h}$} \\
\hline Total & 2230.07 & 524.35 & N/A & N/A & 344.68 & 6.07 \\
\hline
\end{tabular}

per annum. The land area of the facility is calculated at 1 hectare while the building and office area is $1000 \mathrm{~m}^{2}$. The cost of equipment purchase, installation, annualised cost and the cost in $€ / \mathrm{t}$ of pellets produced for the base case scenario are summarised in Table 6. The capital cost of the equipment for setup of the pellet production plant is $€ 6.98 / \mathrm{t}$ of pellets. The annual production capacity of the plant has a bearing on the capital cost of the equipment which is not proportional to the production capacity. By reducing the annual production capacity to $34,080 \mathrm{t}$ (pellet mill capacity $-6 \mathrm{t} / \mathrm{h}$ ), the capital cost of the equipment increases to $€ 8.40 / \mathrm{t}$. In increasing the annual production capacity to $56,800 t$ (pellet mill capacity $10 \mathrm{t} / \mathrm{h}$ ), the capital cost of the equipment can be reduced to $€ 6.07$ / t. These figures are summarised in Table 7.

In calculating the operating costs of each piece of equipment the energy demand (electricity and agricultural diesel fuel) was obtained from the relevant suppliers or manufacturers and computed using published energy costs ${ }^{2}$.

\footnotetext{
${ }^{2}$ Amandus Kahl GmbH and Co. KG, Postfach 12 46, 21452 Reinbek, Germany. Personal communication - Pellet equipment costs.
}

Electricity energy costs were calculated at a rate of $€ 0.109$ / $\mathrm{kWh}^{3}$ while agricultural diesel fuel costs were calculated at a rate of $€ 0.77$ / 1 [22]. Annual utilisation period of the industrial loader is considered to be $30 \%$ of the production hours and $10 \%$ of the production hours for the forklift truck. The total operating costs include the annual cost of maintenance of each piece of equipment. Personnel cost includes costs of personnel in the production, marketing and office and administration [23]. Three production personnel are required for each 8 hour shift regardless of the plant size, while office and administration considers a receptionist and manager, two personnel each for one 8 hour shift per day.

The operating costs for the base case scenario are $€ 27.64$ / $\mathrm{t}$ of pellets produced. As aforementioned the operating cost

C \& L Industries Limited, Unit 1, Liosban Industrial Estate, Tuam Road, Galway, Ireland. Agent for BOGE compressors. Personal Communication - Air compressor plant costs.

Mc Hale Plant Sales, Birdhill, Co. Tipperary, Ireland. Personal communication - Plant equipment costs.

${ }^{3}$ Jones Oil depots. www.jonesoil.ie. Personal communication - Agricultural diesel cost per litre. 
Table 8. Operating Cost of Equipment for the Pellet Production Plant

\begin{tabular}{|l|c|c|c|}
\hline \multicolumn{1}{|c|}{ Equipment } & Operating Cost $(\boldsymbol{\epsilon} / \mathbf{t})$ & Maintenance $(\boldsymbol{\epsilon} / \mathbf{t})$ & Total $(\boldsymbol{\epsilon} / \mathbf{t})$ \\
\hline \hline Straw Grinding Plant & 7.22 & 0.89 & 0.11 \\
\hline Pelleting \& Cooling Plant & 7.90 & 0.05 & 0.04 \\
\hline Compressed Air Plant & 0.10 & 0.05 & 0.13 \\
\hline Packaging Unit & 0.30 & 0.01 & 0.01 \\
\hline Storage Bin & N/A & 0.04 & 0.17 \\
\hline Industrial Loader & 0.13 & 0.01 & 0.04 \\
\hline Fork Lift Truck & 0.03 & 0.20 & 0.38 \\
\hline Office \& Building & 0.18 & 0.09 & 0.09 \\
\hline Land & N/A & N/A & 9.31 \\
\hline Personnel Costs & 9.31 & $\mathbf{2 . 4 7}$ & $\mathbf{2 7 . 6 4}$ \\
\hline Total & $\mathbf{2 5 . 1 7}$ & & \\
\hline
\end{tabular}

Table 9. Cost of Non-Woody Biomass Pellet Production for The Base Case (2009 Euro)

\begin{tabular}{|c|c|c|c|c|}
\hline Pellet Process Operations & $\begin{array}{l}\text { Capital Cost } \\
(€ / t)\end{array}$ & $\begin{array}{c}\text { Operating Cost } \\
\qquad(€ / t)\end{array}$ & $\begin{array}{l}\text { Total Cost } \\
\qquad(€ / t)\end{array}$ & $\begin{array}{c}\text { Percent Cost Distribu- } \\
\text { tion }\end{array}$ \\
\hline Raw Material * & 66.33 & - & 66.33 & 65.9 \\
\hline Straw Grinding Plant & 1.78 & 8.11 & 9.89 & 9.7 \\
\hline Pelleting \& Cooling Plant & 2.47 & 9.04 & 11.51 & 11.3 \\
\hline Compressed Air Plant & 0.02 & 0.16 & 0.18 & 0.2 \\
\hline Packaging Unit & 0.35 & 0.35 & 0.70 & 0.7 \\
\hline Storage Bin & 0.06 & 0.01 & 0.07 & 0.1 \\
\hline Industrial Loader & 0.30 & 0.17 & 0.47 & 0.5 \\
\hline Land Use & 0.38 & 0.09 & 0.47 & 0.5 \\
\hline Personnel Costs & - & 9.31 & 9.31 & 9.2 \\
\hline Total Cost & 73.31 & 27.64 & 100.95 & - \\
\hline
\end{tabular}

*Average of the highest cost option of all the biomass feedstock's - includes storage, drying \& transport

of the pellet production plant also varies depending on the annual production capacity. The operating costs for a plant capacity of $6 \mathrm{t} / \mathrm{h}$ and $10 \mathrm{t} / \mathrm{h}$ are $€ 36.36 / \mathrm{t}$ and $€ 22.31 / \mathrm{t}$ of pellets produced respectively.

Table 9 summarises the total cost of producing pellets from non-woody biomass including the cost of the biomass feedstock. With a production capacity of $8 \mathrm{t} / \mathrm{h}$ as for the base case scenario the total production cost of non-woody biomass pellets is $€ 100.95 / \mathrm{t}$. This production cost can be reduced without increasing production capacity depending on the biomass feedstock and the storage, drying and transport operations employed. By reducing the production capacity to $6 \mathrm{t} / \mathrm{h}$ the total production cost increases to $€ 111.10$ / $t$ for the same assumptions as that of the base case scenario. In increasing the production capacity to $10 \mathrm{t} / \mathrm{h}$ the total production cost decreases to $€ 94.70$ / $\mathrm{t}$.

\section{DISCUSSION}

In determining the economic feasibility of producing biofuel pellets from non-woody biomass, it is important to consider all costs associated with the process. These costs which are included in the above study include the farm gate 
price of non-woody biomass (production - establishment and harvest costs, storage and drying costs), transportation to the pelleting plant and the cost of the pelleting process. The costs outlined are a base cost and do not consider any profit margin either for the biomass producer or the pellet manufacturer.

In considering cereal straws as a source of biomass feedstock for pelleting it is equally important to determine the opportunity cost of the feedstock as well as the production cost or market price. In removing the crops straw (wheat, barley, oats and rape straw) from the field valuable nutrients in the material are lost in comparison to if the straw was chopped and ploughed back at tillage. The cost of replacing these nutrients with artificial potassium and phosphorus fertilisers was considered. The cost of baling the straw must also be considered when determining the market value and the associated costs of the feedstock $(€ 15 / \mathrm{t}$ for $1.2 \mathrm{~m} \times 1.2 \mathrm{~m} \times 2.4 \mathrm{~m}$ large bale). In considering cereal straws as a feedstock source for pellet production wheaten straw is the least expensive $(€ 32 / \mathrm{t} \mathrm{dm})$ while barley straw incurs the greatest expense $(€ 45 / \mathrm{t} \mathrm{dm})$.

In utilising miscanthus and willow as a source of feedstock for pelleting the cost of the material are $€ 51 / \mathrm{t} \mathrm{dm}$ and $€ 82$ / t dm respectively. Neither willow nor miscanthus is considered to have an opportunity cost as a replacement fertiliser as the primary crop is the biomass feedstock. Developed markets in Ireland for both energy crops is mainly as a source of biomass for fuel with miscanthus also being utilised as a bedding for animals mainly horses.

Storage of biomass is essential to ensure a year round supply of dry, quality feedstock to the pelleting plant. For baled biomass, roofed structures or covered storage can be utilised. Covered storage using 1200 gauge plastic is the most cost effective solution although existing farm buildings could also be utilised. The building of new storage facilities purposely for storage requires substantial investment $(€ 1.69$ $€ 1.80$ p.a / t dm). When considering storing baled miscanthus under cover, heavy duty covers are essential to avoid the stems piercing and damaging the cover. While a tarpaulin cover incurs the greatest cost $(€ 2.05$ p.a / t dm) this cost could be reduced by using recycled tarpaulins instead of new tarpaulins. Where ground conditions are favourable no hardcore sub-floor may be required further reducing the cost of storage both covered and roofed structures.

In storing chipped material, suitable surface and covering is essential to reduce moisture content and prevent decomposition of the material. Chipped material may be stored in existing buildings with ducted ventilation, purpose built buildings with drying floors or as considered for the purpose of this research on a concrete slab, covered and ventilated using ducting. Storage of chips incurs the greatest storage cost at $€ 6.42 \mathrm{p}$.a / t dm.

For drying baled biomass in covered storage, natural ventilation is adequate. This is due to the relative low moisture of the crops at harvest. Due to the high initial moisture content of willow chip at harvest forced ventilation of the chip during storage is essential. Drying costs for willow chip using forced ventilation of ambient air is $€ 7$ p.a. / t.
In transporting baled biomass the cost associated with both articulated haulage and tractor and trailer was investigated. The greatest influence on the transportation cost is the bulk density of the product. Both the diesel fuel cost and the distance travelled are also critical factors in considering the transportation type. While the cost of transporting baled biomass by tractor and trailer is cheaper per tonne $(€ 6 / \mathrm{t} \mathrm{dm})$ than that of articulated haulage $(€ 12.50 / \mathrm{tdm})$, the practicalities of this type of haulage must be considered. The maximum realistic travel distance by tractor and trailer is $50 \mathrm{~km}$ and may even be limited to $30 \mathrm{~km}$ depending on the class of roads. Above these distances the travel time is a constraint. Where large volumes of feedstock are to be hauled over distances greater than $30 \mathrm{~km}$, articulated haulage is the more efficient option due to the faster turn around time especially when road classes are primary routes.

The transportation cost of willow chip is greater than that of baled biomass in particular when comparing to tractor and trailer transportation. The main reason for this is the large volume and low payload of chipped biomass. Transportation of willow chip by tractor and trailer in comparison to articulated haulage is approximately $€ 0.50 / \mathrm{t} \mathrm{dm}$ more cost effective. As aforementioned the travel distance and volume of feedstock to be hauled are major considerations when utilising tractor and trailer transportation. This is particularly true for willow chip considering a payload of $8 \mathrm{t} \mathrm{dm}$ for tractor and trailer transportation in comparison to $14.5 \mathrm{t} \mathrm{dm}$ for articulated haulage.

Wheaten straw whether transported by tractor and trailer or articulated haulage ( $€ 39 / \mathrm{tdm}$ and $€ 51 / \mathrm{t} \mathrm{dm}$ respectively - payload $15 \mathrm{t} \mathrm{dm}$ ) is the lowest cost option for biomass delivered to the pelleting plant. Willow chip as a source of biomass for pellet production incurs the largest cost $(€ 108 / \mathrm{t}$ $\mathrm{dm}$ ) and realistically will not be considered as a feedstock for pellet production.

The scale of capacity of a pelleting plant significantly affects both the capital and operating costs of the pelleting plant. The greater the production capacities of a pelleting plant the lower the capital and operating costs of the plant. All capital cost components follow an economy of scale hence expansion of any unit capacity will reduce capital cost and operating cost non-proportional to the actual size of the expansion.

The total pellet production cost for the base case scenario of $8 \mathrm{t} / \mathrm{h}$ capacity of pellets is $€ 101 / \mathrm{t}$. In decreasing the production capacity to $6 \mathrm{t} / \mathrm{h}$ the total cost increased by $€ 10 / \mathrm{t}$ while increasing production to $10 \mathrm{t} / \mathrm{h}$ saw a decrease of $€ 6 /$ $\mathrm{t}$ in the total cost of producing non-woody biomass pellets. Assuming an average energy value of $14.5 \mathrm{GJ} / \mathrm{t}$ at $15 \%$ moisture content for non-woody biomass this equates to $€ 7$ / GJ of energy for the base case scenario of $8 \mathrm{t} / \mathrm{h}$ pellet production [19]. The current cost of home heating oil (kerosene) is $€ 16$ / GJ and for natural gas varies between $€ 30$ / GJ for small household users ( $<20$ GJ p.a.) to $€ 14.50$ / GJ for larger household users ( $\geq 200$ GJ p.a.) $[24,25]$.

The cost of biomass feedstock per tonne delivered to the processing plant depends on several factors. The type of storage utilised on-farm prior to delivery, drying methods 
and the transportation type and distance travelled effect the cost of the feedstock. The raw material cost is the greatest cost associated with pellet production. The raw material cost considered for this analysis of $€ 67 / / \mathrm{t} \mathrm{dm}$ over a travel distance of $50 \mathrm{~km}$ is the average cost of all feedstock's accounting for $66 \%$ of the overall cost. By reducing the feedstock cost per tonne the pellet production cost can be reduced. In considering only cereal straws and miscanthus as the feedstock's and neglecting willow due to the high cost per tonne (€108/ t dm) the feedstock cost can be reduced to $€ 58 / \mathrm{t} \mathrm{dm}$. By optimising the operations associated with the feedstock production, storage, drying and transportation operations the cost of the aforementioned feedstock's can further be reduced to $€ 46 / \mathrm{t} \mathrm{dm}$.

Other major cost components associated with the production of pellets from non-woody biomass are the pelleting and cooling plant (11\%), the straw grinding plant (10\%) and personnel costs $(9 \%)$. The pelleting and straw grinding plant also have the greatest operating costs $(62 \%$ of total operating costs including maintenance) with a maintenance cost of $10 \%$ of the purchase cost in comparison to $2 \%$ for all other equipment. In this study no additional binders are considered which would further increase the pellet production cost per tonne if utilised. While personnel costs are one of the major factors personnel requirements depend on the production operation and administrative strategies.

\section{CONCLUSIONS}

In harvesting and baling cereal straw and miscanthus in $1.2 \mathrm{~m} \times 1.2 \mathrm{~m} \times 2.4 \mathrm{~m}$ large bales the production cost varies from $€ 31 / \mathrm{t} \mathrm{dm}$ for wheaten straw to $€ 51 / \mathrm{t} \mathrm{dm}$ for miscanthus. In investigating the storage costs of baled biomass outdoor covered storage using heavy duty (1200 gauge) plastic is the least expensive storage option. For baled biomass natural ventilation in storage is adequate for drying due to the low initial moisture content of the biomass feedstock at harvest.

When considering willow as a feedstock for pellet production the cost is $€ 108 / \mathrm{t} \mathrm{dm}$. Storage of willow chip is also more costly than that of baled biomass due to the storage requirements to prevent contamination and decomposition of the stored material. Forced ventilation either by ambient or heated air is essential when storing willow chips so as to facilitate drying and prevent heating. This is due to the high initial moisture content of the feedstock at harvest $(50-70 \%$ moisture content). Realistically willow chip would not be a feasible feedstock for pellet production and would be sold in chip form as an energy fuel instead of for processing into biofuel pellets resulting in less drying of the material required.

For both baled and chipped biomass, tractor and trailer transportation is less expensive than articulated haulage. This type of transportation is only suited to short journeys no greater than $50 \mathrm{~km}$.

Raw material is the major cost factor associated with pellet production. In reducing the cost of delivered feedstock by optimising the production, storage, drying and transportation systems to meet the pelleting plants requirements the overall cost can be reduced. The production capacity of any pellet- ing operation significantly influences the cost per tonne of pellets produced. For a production capacity of $8 \mathrm{t} / \mathrm{h}$ the capital and operating costs per tonne of pellets produced are $€ 73$ and $€ 28$ respectively. The overall production cost is $€ 101 / \mathrm{t}$. By increasing the production capacity to $10 \mathrm{t} / \mathrm{h}$ the overall cost can be reduced by $€ 6 / \mathrm{t}$ of pellets produced.

Given the current energy prices for kerosene home heating oil at $€ 16$ / GJ and natural gas at between $€ 14.50$ / GJ and $€ 30 / \mathrm{GJ}$ the production of pellets from non-woody biomass at a base cost excluding all profit margins at €7 / GJ could be economically feasible.

\section{ACKNOWLEDGEMENTS}

Funding for this research was provided through the Department of Agriculture and Food Stimulus Fund Ireland.

\section{NOMENCLATURE}

\begin{tabular}{|c|c|c|}
\hline $\mathrm{CHP}$ & $=$ & Combined Heat and Power \\
\hline $\mathrm{CO}_{2}$ & $=$ & Carbon Dioxide \\
\hline GHG & $=$ & Greenhouse Gas \\
\hline GJ p.a & $=$ & Gigajoule per annum \\
\hline $\mathrm{GJ} / \mathrm{t}$ & $=$ & GigaJoule per tonne \\
\hline $\mathrm{C}_{\mathrm{c}}$ & $=$ & Total Capital Cost $(€ /$ year $)$ \\
\hline $\mathrm{C}_{1} \& \mathrm{C}_{2}$ & $=$ & Equipment capacity (tonnes per hour) \\
\hline $\mathrm{C}_{\mathrm{eq}}$ & $=$ & Cost of equipment \\
\hline $\mathrm{C}_{\mathrm{op}}$ & $=$ & Operating cost \\
\hline $\mathrm{C}_{\mathrm{T}}$ & $=$ & Total cost \\
\hline $\mathrm{G}_{\mathrm{p}}$ & $=$ & Production rate (tonnes per hour) \\
\hline $\mathrm{N}$ & $=$ & Lifetime of the equipment (years) \\
\hline $\mathrm{e}$ & $=$ & Capital recovery factor \\
\hline $\mathrm{g}$ & $=$ & Exponent for process equipment \\
\hline ha & $=$ & Hectare \\
\hline $\mathrm{i}$ & $=$ & interest rate \\
\hline $\mathrm{kg} / \mathrm{dm} \mathrm{m}{ }^{3}$ & $=$ & Kilograms per cubic metre dry matter \\
\hline $\mathrm{km}$ & $=$ & Kilometre \\
\hline $\mathrm{kWh}$ & $=$ & kiloWatt hour \\
\hline 1 & $=$ & litre \\
\hline $\mathrm{m}$ & $=$ & Metres \\
\hline $\mathrm{m}^{2}$ & $=$ & Metres squared \\
\hline $\mathrm{m}^{3}$ & $=$ & Cubic metres \\
\hline m.c.w.b. & $=$ & Moisture content wet basis \\
\hline $\mathrm{mm}$ & $=$ & Millimetre \\
\hline $\mathrm{t}_{\mathrm{op}}$ & $=$ & $\begin{array}{l}\text { Total operational hours of the plant per } \\
\text { year }\end{array}$ \\
\hline $\mathrm{t} \mathrm{dm}$ & $=$ & tonnes dry matter \\
\hline $\mathrm{t} / \mathrm{h}$ & $=$ & tonnes per hour \\
\hline wb & $=$ & Wet basis \\
\hline
\end{tabular}




\section{REFERENCES}

[1] Energy Policy Statistical Support Unit. Energy in Ireland 19902007. Sustainable Energy Ireland, 2008, pp. 51-53. [Accessed on: 26 March 2009] Available at: www.sei.ie

[2] McKendry, P. Energy production from biomass (part 1): overview of biomass. Resource Technol., 2002, 83, 37-46.

[3] Pastre O. EUBIA - Pellets for Europe - Analysis of the technical obstacles related to the production and utilisation of fuel pellets made from agricultural residues. ALTENER 2002-012-137-160.

[4] AEBIOM - European Biomass Association. A Pellet Road Map for Europe - November 2008.

[5] Styles, D.; Thorne, F.; Jones, M.B. Energy crops in Ireland: an economic comparison of willow and miscanthus production with conventional farming systems. Biomass Bioenergy, 2008, 32, 407421.

[6] Huisman, W.; Venturi, P.; Molenaar, J. Costs of supply chains of miscanthus giganteus. Indust. Crops Prod., 1997, 6, 353-366.

[7] Mani, S.; Sokhansanj, S.; Bi, X.; Turhollow, A. Economics of producing fuel pellets from biomass. Appl. Eng. Agric., 2006, 22(3), 421-426.

[8] Euro Exchange rates. Official journal of the European Communities. 2002/C1/02 [Accessed on: 02 February 2009] Available at: www.eurlex.europa.eu/LexUriServ.do?uri=OJ:C:2002:001:002:000 2:EN:PDF

[9] Production of big straw bales, straw, pellets, transport and storage for power plants and CHP plants - Fact sheet 12 - Denmark. [Accessed on: 16th January 2009]. Available at: www.eubionet.net

[10] El, Bassam, N.; Huismann, W. Harvesting and Storage of Miscanthus; Jones M.B.; Walsh M., Eds. Miscanthus for Energy and Fibre. James and James Scientific Publishing Ltd.: UK, 2001, pp. 86-108.

[11] Nolan, A.; McDonnell, K.; McSiurtain, M.; Carroll, J.P.; Finnan, J.; Rice, B. Conservation of miscanthus in bale form. Biosyst. Eng., 2009, doi:10.1016/j.biosystemseng.209.06.025

[12] Garstang J. Transport Issues. Presented at National Energy Crops Conference, London, England, September 2001
[13] Urbanowski, E. Strategic Analysis of a Pellet Fuel Opportunity in Northwest British Columbia. MS thesis. University of Saskatchewan, Faculty of Business Administration 1984.

[14] Williams, N.K.; Lynch, D. L. Wood Pellet Manufacturing Production Equipment and Cost Study for Walden, Colorada. Department of Forest Sciences, Colorado State University 1995.

[15] Thek, G.; Obernberger, I. Wood pellet production costs under Austrian and in comparison to Swedish framework conditions. Biomass Bioenergy, 2004, 27, 671-693.

[16] Euro to Dollar conversion. [Accessed on: 15 April 2009] Available at: www.marketwatch.com/news/story/dollar-loses-11-vs-euro-in2006-on-rate-outlook-flat-vs-yen

[17] Consumer Price Index (CPI) from 1665 to 2012. [Accessed on: 30 April 2009] Available at: www.austintxgensoc.org/calculatecpi.php

[18] Management Data for Farm Planning. Teagasc Crops Research Centre, Oak Park, Carlow, Ireland 2008.

[19] Straw fertiliser value - Fact sheet Tillage Specialists July 2008. Teagasc Crops Research Centre, Oak Park, Carlow, Ireland 2008

[20] Road Traffic (Construction and use of vehicles) regulations 2003 Leaflet No. 1 - Guidelines on maximum weight and dimensions of mechanically propelled vehicles and trailers. Road Safety Authority of Ireland - Vehicle Standards Section. Available at: www.RSA.ie

[21] Murphy, G. Fitpac Transport Model. Prof Glen Murphy, University College Dublin: Ireland 2008.

[22] Energy Policy Statistical Support Unit. Understanding Electricity and Gas Prices in Ireland. Sustainable Energy Ireland, 2009, pp. 14-17. [Accessed on: 06 May 2009] Available at: www.sei.ie

[23] Pay scales by job in Ireland. Available at: www.payscale.com [Accessed on: 06 May 2009].

[24] Prices of electricity, gas and oil in Ireland. [Accessed on: 14 May 2009] Available at: www.irishlinks.co.uk/electricity-gas-oil-prices

[25] Energy Policy Statistical Support Unit. Understanding Electricity and Gas prices in Ireland. Sustainable Energy Ireland, 2009, pp. 2631. Available at: www.sei.ie [Accessed on: 06 May 2009].

Received: July 23, 2009

(C) Nolan et al.; Licensee Bentham Open.

This is an open access article licensed under the terms of the Creative Commons Attribution Non-Commercial License (http://creativecommons.org/licenses/by-nc/3.0/) which permits unrestricted, non-commercial use, distribution and reproduction in any medium, provided the work is properly cited. 